\title{
Relationships Between Climatic Variables and Tree- Ring Width of Silver Fir (Abies alba Mill.) in Kozara National Park (Bosnia and Herzegovina)
}

\author{
Jelena Subotić ${ }^{1}$, Vojislav Dukići ${ }^{1 *}$, Tatjana Popov $^{2}$, Goran Trbić $^{2}$, Zoran Maunaga ${ }^{1}$, Danijela Petrović ${ }^{1}$
}

(1) University of Banja Luka, Faculty of Forestry, Stepe Stepanovića 75a, BA-7800 Banja Luka, Bosnia and Herzegovina; (2) University of Banja Luka, Faculty of Natural Sciences and Mathematics, Dr. Mladena Stojanovića 2, BA-7800 Banja Luka, Bosnia and Herzegovina

* Correspondence: e-mail: vojislav.dukic@sf.unibl.org

\begin{abstract}
Citation: Subotić J, Dukić V, Popov T, Trbić G, Maunaga Z, Petrović D, 2020. Relationships Between Climatic Variables and Tree-Ring Width of Silver Fir (Abies alba Mill.) in Kozara National Park (Bosnia and Herzegovina). South-east Eur for 11(1): 1727. https://doi.org/10.15177/seefor.20-05. Received: 2 Dec 2019; Revised: 2 Feb 2020; Accepted: 5 Feb 2020; Published online: 30 Apr 2020
\end{abstract}

\begin{abstract}
Silver fir (Abies alba Mill.) is the most common conifer species in Bosnia and Herzegovina. The paper describes the development of a silver fir master tree-ring chronology from Kozara National Park and analyzes the influence of the climate conditions on tree-ring widths. The knowledge concerning the effect of climate on cambium activity and, as a result, on tree growth is of great importance for silviculture, which is particularly complex in terms of deterioration of health condition. Four sites were selected for sampling at Kozara National Park. At each sampling site, 15 dominant trees were drilled with Pressler's increment borer at breast height. The development of chronology included three steps: i) cross-dating of a series of tree-ring width and checking of their quality using the COFECHA program, ii) data standardization in the ARSTAN program, and iii) master chronology development. Correlation analysis was performed in order to determine the links between tree-ring width and climate (primarily temperature and precipitation). In the 88-year-long master chronology, pointer years analysis identified five positive and nine negative years. Correlation analysis revealed that precipitation had stronger and more significant impact on silver fir radial growth, particularly at the beginning of the growing season, in April and May ( $r=0.175$ and $r=0.318$, respectively), and in the crucial July-September period ( $r$ in the range of 0.143-0.222). The highest negative correlation coefficient with temperature was determined for September of the previous year $(r=-0.282)$ and then for summer months (July and August) of the current year ( $r=-0.184$ and $r=-0.272$, respectively). In addition, statistically significant correlation between radial growth and the Forestry Aridity Index was determined $(r=-0.390)$. The results of tree-ring width climate analysis obtained in this study are in accordance with other studies carried out in Bosnia and Herzegovina and in the surrounding area.
\end{abstract}

Keywords: dendroecology; silver fir; temperature; precipitation; forestry aridity index

\section{INTRODUCTION}

Silver fir (Abies alba Mill.) grows naturally in central and southern Europe. In Bosnia and Herzegovina, fir is found in mixed beech and fir forests, beech, fir and spruce forests and very rarely in pure fir forests. In the mountain belt fir forms forests with spruce, sometimes with Scots pine, but also with beech. The most significant forests in Bosnia and Herzegovina are the community of beech-fir (Abieti fagetum) forests (Stefanović 1977, Stefanović et al. 1983,
Beus 1984). According to the National Forest Inventory, silver fir is the most common conifer species in Bosnia and Herzegovina. Beech and fir (with spruce) forests, i.e. forests with fir (pure and mixed), cover 599,000 ha or $28 \%$ of the total forest area (high and coppice forests). The highest stock of wood and the highest increment for high forests in Bosnia and Herzegovina were determined in these forests with fir (Čabaravdić et al. 2016).

According to Smith and Lewis (2007), dendrochronology is a scientific discipline that studies dating and annual 
growth of rings in forest trees and shrubs. If all trees at one locality are influenced by common environmental factors such as climate, cross-dating provides a precise chronological record that can be used in dating events or describing differences in environmental conditions. Dendrochronology as a scientific discipline provides data on tree-ring growth, which can be used in a number of other scientific fields. By combining dendrochronology with these scientific disciplines, subdisciplines within dendrochronology have been differentiated, and one of the most important is dendroecology.

According to Amoroso et al. (2017), the term "dendroecology" is a relatively new term that was originally used in a much narrower sense. While dendroclimatology used past tree-growth patterns to reconstruct climate, dendroecology focused on how climate and other factors directly and indirectly influenced past tree-growth patterns. Dendroecology is a significant component of applied ecological research, providing important historical context for adapting the existing forest management strategies to mitigate and respond to current and future global environmental changes (Amoroso et al. 2017).

Silver fir has been the subject of research in a number of dendrochronological studies in Europe and in the Balkans (Rolland 1983, Levanič 1996, Smith et al. 1999, Toromani and Bojaxhi 2010, Bijak 2010, Carrer et al. 2010, Mazza 2013, Koprowski 2013, Jović et al. 2018).

Silver fir forests are endangered in some parts of Europe. The results of several studies suggested that fir is threatened with complete disappearance from the forests in central Europe (Elling et al. 1999, Badea et al. 2004, Filipiak
2005, Filipiak 2006, Filipiak and Napierała-Filipak 2009). The health status of silver fir forests in Bosnia and Herzegovina is deteriorating due to inadequate management. Silviculture does not take into account the ecological characteristics of common silver fir. This disrupts the stability of fir forests, which ultimately causes the spread of mistletoe Viscum album var. abietis Beck. as a primary parasite, followed by much more dangerous secondary pathogens (Uščuplić 1992, Uščuplić et al. 2007).

The knowledge about the effect of climate on cambium activity and, as a result, on tree growth is of great importance for silviculture, which is particularly complex in terms of the stated threats to firs in Bosnia and Herzegovina, i.e. their deterioration of health condition. The aim of the current study was to establish a silver fir tree-ring chronology from Kozara National Park and to analyze the effect of climatic variables on tree-ring widths.

\section{MATERIALS AND METHODS}

\section{Study Area}

The study area covers the area of Kozara National Park, which encompasses the central part of the eponymous mountain, located in the north-western part of Bosnia and Herzegovina (Figure 1). Kozara National Park is a member of the Federation of Nature and National Parks of Europe (EUROPARC Federation). The total area of the national park is 3,907.54 ha. The largest part of the national park is covered with high beech and fir forests $(2,222.97$ ha or $57 \%$ of the total area).

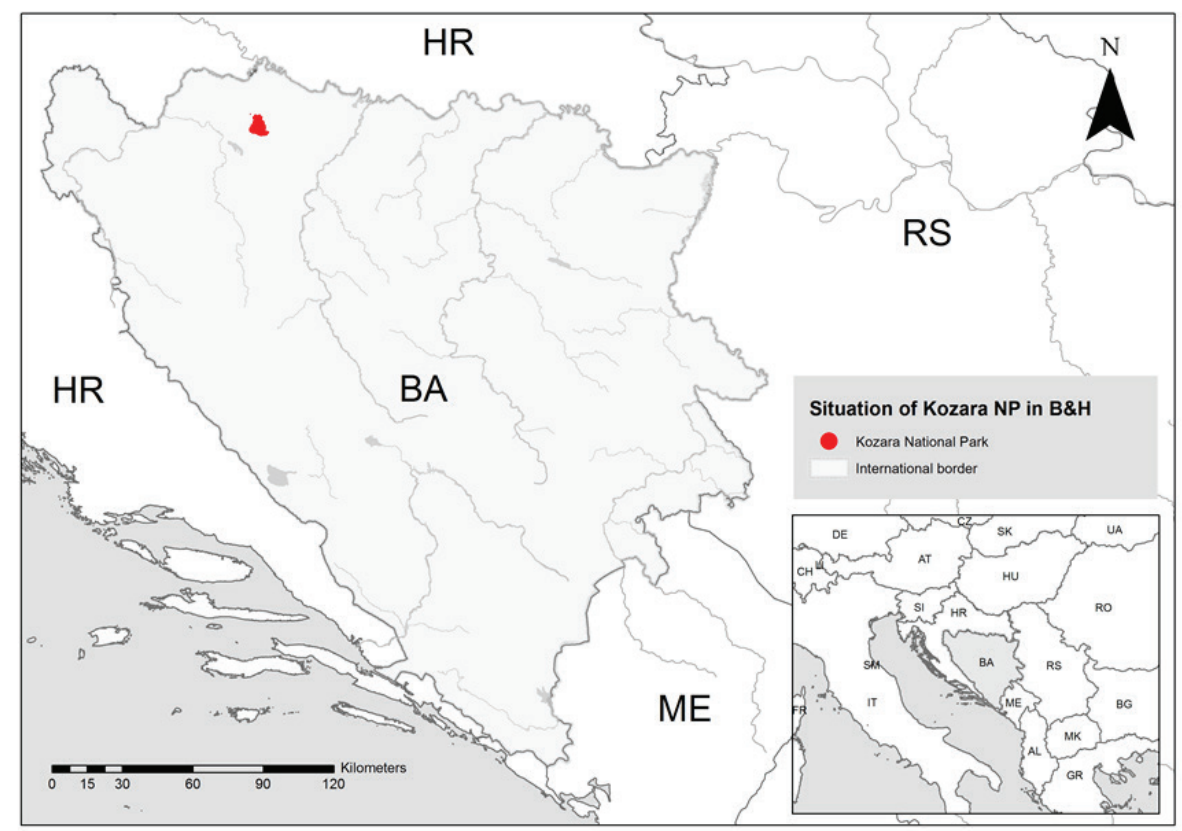

Figure 1. Geographical location of the study area. 


\section{Data Sampling}

Based on the terrain reconnaissance, four sites (plots) were selected for sampling at Kozara National Park. In September 2015, core samples were taken from dominant silver fir trees in overstocked stands. All plots were located in the belt of Peripannonian beech and fir forests (Festuco drymeiae-Abietetum Vukelić et Baričević 2007), which are dominant in the central and northern, cooler part of the mountain. The dominant species in these forests is silver fir, which on the northern side of the mountain, atypically for such latitudes, extends to a very low altitude (to about 200 $\mathrm{m}$ above sea level). For all sample plots, the characteristic geological substrate was the Eocene flysch, with a very deep eutric cambisol. Samples were collected at different expositions (NNE, SW, NE and N) and in slopes ranging from 12 to $25^{\circ}$ (Table 1 ).

At each sampling site, 15 dominant trees (larger than the average trees in the stand, with crowns extending above the general level of the crown cover and with well-developed crowns) were drilled with Pressler's increment borer (core diameters: $5.15 \mathrm{~mm}$ ) at breast height $(1.30 \mathrm{~m})$. From each tree, two cores from opposite sides were extracted. Previous studies determined that minimum sample size for establishing a quality individual chronology of the site is 15 trees, if two increment cores are taken from each tree (Fritts 1976, Levanič 1996). Two out or three additional trees were drilled to serve as a substitute, in case that some of the sampled trees have atypical growth (overtopped trees, heart rot, missing or false tree-rings), so it could be difficult to cross-date them, or if some samples are damaged in the measurement preparation. The decay of wood at the center of the trunk was found in a considerable number of trees, which reflected in the length of the obtained chronology. The cores were scanned with a high-performance scanner: the Epson Perfection V30 Photo scanner. The tree-ring width was measured with the CooRecorder 7.6 and CDendro 7.6 software (available at http://www.cybis.se/forfun/dendro/).

\section{Chronology Development}

The procedure of chronology development consisted of three steps: cross-dating, data standardization and development of master chronology. Cross-dating technique ensures that each individual tree-ring is assigned to its exact year of formation. Cross-dating was done by using visual onscreen techniques (skeleton plotting) with CDendro software and statistical methods with the use of COFECHA specialized computer program (Holmes 1983, Grissino-Mayer 2001). The COFECHA program adds a high degree of confidence that tree-ring samples have been cross-dated correctly and measured accurately, ensuring that the environmental signal is maximized (Grissino-Mayer 2001). The first phase of processing in the COFECHA program was the detection of trees that significantly differ from the average value (i.e. trees which displayed a low correlation coefficient with the master chronology) and for which a larger number of "problematic segments" were identified. After this first phase, all trees that could not be synchronized (due to the appearance of overtopped trees which is very characteristic for firs, or the appearance of missing or false tree-rings), as well as those trees whose samples were damaged in transport or preparation for the analysis, were removed from further processing. Silver fir is a shade-tolerant species. Young fir trees can endure long periods in the deep shade, and continue their normal development when large quantities of light become available. Samples from additional trees replaced the eliminated samples.

The standardization (detrending) of tree-ring width time series is a traditional procedure in dendrochronology and essentially represents the elimination of the so-called agerelated trend. The standardization of tree-ring width time series was performed using the ARSTAN program (Cook 1985, Cook and Holmes 1997). To remove the age-related trend cubic smoothing splines were used. Flexible cubic spline curves are very efficient at removing both the long-term trend and the effect of localized disturbance events, always present in the course of forest dynamics, which can lead to abrupt growth responses (reduction or release) that can persist in single trees even for many years after the disturbance event and conceal or fade the climatic signal retained in the tree-ring series (Cook and Peters 1981). Mean chronologies for each site were calculated as the biweight robust mean of detrended individual series (Cook 1985). For individual raw series, and for the mean chronologies, mean sensitivity was calculated to assess the high-frequency variations (Fritts 1976), and the first-order autocorrelation to measure the influence of the previous year's growth on the current ring. The results of the processing in the ARSTAN program are three curves, i.e. three versions of the chronology: standardized (std), residual (res) and arstan (ars). The ars chronology performed by the multivariate autoregressive analysis procedure has the best climate signal and was therefore used to study the influence of climatic variables on the tree-ring width.

Table 1. Characteristics of the sampling sites.

\begin{tabular}{ccccc}
\hline Site number & $\mathbf{1}$ & $\mathbf{2}$ & $\mathbf{3}$ & $\mathbf{4}$ \\
\hline Latitude & $45^{\circ} 0^{\prime} 51.8^{\prime \prime} \mathrm{N}$ & $45^{\circ} 0^{\prime} 49.7^{\prime \prime} \mathrm{N}$ & $45^{\circ} 0^{\prime} 48.5^{\prime \prime} \mathrm{N}$ & $45^{\circ} 0^{\prime} 12.5^{\prime \prime} \mathrm{N}$ \\
Longitude & $16^{\circ} 54^{\prime} 40.8^{\prime \prime} \mathrm{E}$ & $16^{\circ} 54^{\prime} 27.2^{\prime \prime} \mathrm{E}$ & $16^{\circ} 55^{\prime} 6.4^{\prime \prime} \mathrm{E}$ & $16^{\circ} 53^{\prime} 39.0^{\prime \prime} \mathrm{E}$ \\
Geological substrate & Eocene flysch & Eocene flysch & Eocene flysch & Eocene flysch \\
Soil & Eutric cambisol & Eutric cambisol & Eutric cambisol & Eutric cambisol \\
Altitude (m a.s.l.) & 780 & 790 & 735 & $\mathrm{NE}$ \\
Exposure & $\mathrm{NNE}$ & SW & 12 & $\mathrm{~N}$ \\
Slope $\left({ }^{\circ}\right)$ & 15 & 22 & & 25 \\
\hline
\end{tabular}




\section{Meteorological Data}

For the calculation of the links between tree-ring width and climatic variables, primarily temperature and precipitation, data from the nearest meteorological station were used, that is, Prijedor meteorological station, located about $18 \mathrm{~km}$ southwest of the study area. Data on mean monthly temperatures and precipitation, in the 1961-2014 period (data available only for this period) were provided by the Republic Hydrometeorological Service of Republic of Srpska (Table 2).

In addition to temperature and precipitation, the forestry aridity index (FAl) (Führer et al. 2011) was used for the analysis of their combined effect on silver fir radial growth. The relationship between meteorological parameters and trees growth can be characterized by a simplified forestry aridity index: $\mathrm{FAl}=100 \times \mathrm{T}_{\mathrm{VII-VIII}} /\left(\mathrm{P}_{\mathrm{V}-\mathrm{VII}}+\right.$ $\left.P_{\text {VII-VIII }}\right)$, where $T_{\text {VII-VIII }}$ is the average temperature in July and August $\left({ }^{\circ} \mathrm{C}\right), \mathrm{P}_{\mathrm{v}-\mathrm{VII}}$ is the precipitation sum $(\mathrm{mm})$ in the MayJuly periods, and $\mathrm{P}_{\mathrm{VII-VIII}}$ is the precipitation sum $(\mathrm{mm})$ of July and August (Führer et al. 2011). The higher index values suggest more arid climate.

\section{RESULTS}

Basic characteristics of trees and tree-ring width, including mean and maximum tree-ring width, standard deviation, autocorrelation coefficient and mean sensitivity, were calculated for empirical series of Sites 1-4. The mean diameter at breast height of analyzed trees was in the range of 57.6-73.2 $\mathrm{cm}$, whereas the height was in the range of $32.5-36.4 \mathrm{~m}$. The total number of tree segments (1925$1974,1950-1999,1975-2024$ ) at the sites ranged from 31 to 39. At Sites 1, 2 and 4, two problematic segments appeared, and at Site 3 only one, i.e. the share of problematic segments was in the range of $2.94-5.13 \%$, which can be considered as acceptable deviation. The serial intercorrelation of the empirical tree-ring widths ranged from 0.376 to 0.605 . The arithmetic mean of all the individual series of empirical treering width increments ranged from $3.45 \mathrm{~mm}$ at Site 1 to 3.77 $\mathrm{mm}$ at Site 3, i.e. the values were about the same. Filtered (indexed) data, as expected, are characterized by significantly different values of analyzed parameters. Furthermore, the effect of autocorrelation is practically eliminated, which is confirmed by autocorrelation coefficients close to zero. The best results were obtained by analyzing the tree-ring widths from Site 3 , whereas somewhat weaker results were obtained from Site 2 (Table 3).

Height in relation to diameter (in relation to the local site quality classification - uneven-aged stand (Drinić et al. 1990), and average tree-ring widths per sites show that the studied sites are highly productive habitats for silver fir, which was to be expected given the habitat conditions described, primarily soil characteristics (very deep eutric cambisol).

Figure 2 shows the average empirical tree-ring series. The age trend was clearly manifested, i.e. there was a decrease in the mean tree-ring widths at sites with increasing age. It is also noticeable that the tree-ring widths were more variable over the last 20 years than in the previous period.

Table 2. Mean monthly and annual (y) temperature and precipitation in Prijedor during the 1961-2014 period.

\begin{tabular}{cccccccccccccc}
\hline Variable & I & II & III & IV & V & VI & VII & VIII & IX & X & XI & XII & Y \\
\hline $\mathrm{t}\left({ }^{\circ} \mathrm{C}\right)$ & -0.3 & 2.0 & 6.5 & 11.4 & 16.0 & 19.6 & 21.3 & 20.7 & 16.4 & 11.4 & 5.9 & 1.2 & 11 \\
$\mathrm{p}(\mathrm{mm})$ & 62 & 55 & 65 & 81 & 85 & 89 & 80 & 77 & 93 & 80 & 89 & 77 & 931 \\
\hline
\end{tabular}

Table 3. The basic characteristics and dendrochronological-statistical parameters of empirical series of tree-ring width.

\begin{tabular}{ccccc}
\hline Variable & Site 1 & Site 2 & Site 3 & Site 4 \\
\hline $\mathrm{dbh}(\mathrm{cm})$ & 60.4 & 73.2 & 57.6 & 58.5 \\
$\mathrm{~h}(\mathrm{~m})$ & 32.5 & 36.4 & 34.2 & 32.6 \\
\hline No. Years & 1057 & 900 & 931 & 343 \\
No. Segments & 39 & 31 & 1 & 2 \\
No. Problematic segments & 2 & 2 & 0.605 & 0.554 \\
Series intercorrelation & 0.574 & 0.376 & $3.77(1.88-5.42)$ & $3.66(2.78-6.86)$ \\
\hline Mean (mm) & & Unfiltered & $1.77(1.09-4.71)$ & $1.70(1.08-3.06)$ \\
Standard deviation (mm) & $1.51(0.51-2.08)$ & $1.84(0.72-2.68)$ & $0.685(0.403-0.912)$ & $0.795(0.669-0.920)$ \\
Autocorrelation & $0.752(0.429-0.912)$ & $0.813(0.640-0.912)$ & $0.248(0.193-0.311)$ & $0.224(0.108-0.305)$ \\
Mean sensitivity & $0.237(0.169-0.306)$ & $0.220(0.136-0.312)$ & & $0.28(0.16-0.42)$ \\
Standard deviation & $0.28(0.21-0.40)$ & $0.30(0.17-0.47)$ & $0.29(0.16-0.37)$ & 0.007 \\
Autocorrelation & -0.002 & 0.002 & -0.008 & \\
\hline
\end{tabular}




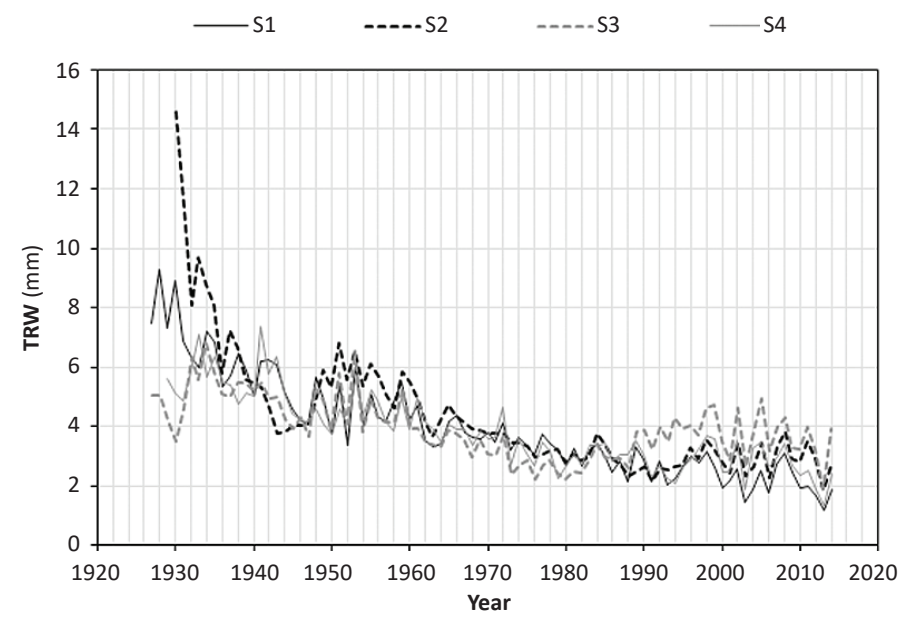

Figure 2. Average empirical tree-ring series per sampling sites.

In order to remove the age related-trends in tree diameter increment, standardization of the original (empirical) data series was performed in the ARSTAN program. During the standardization, each tree-ring width series was fitted with the cubic smoothing spline. After data smoothing, a dimensionless tree-rings width index $\left(\mathrm{I}_{t}\right)$ was calculated. The results of the chronology analysis with the ARSTAN program are three curves, i.e. three versions of the chronology and a comprehensive statistical analysis. The obtained arstan (ars) version of chronologies for the four sampling sites are shown in Figure 3.

The adequacy of merging these four sites' chronologies into one master chronology was determined based on the degree of correlation between chronologies measured by the product moment correlation coefficient and its corresponding t-value, as defined by Baillie and Pilcher (Baillie and Pilcher 1973). Statistically significant positive correlation coefficients were determined between all four sites. The calculated correlation coefficients ranged from 0.647 (between Site 2 and Site 3) to 0.841 (between Site 3 and Site 4). The Gleichläufigkeit (glk) (Huber 1943, Eckstein and Bauch 1969), i.e. the percentage of common signs of year-to-year growth change between two series, was high and statistically significant, ranging from 0.657 to 0.738 . These results showed that there is a significant harmonization and a high similarity between the obtained chronologies (i.e. similar patterns of tree-ring increment) at different sites. This indicates that these chronologies were suitable and a master chronology was developed for the Kozara Mountain area (Table 4).

An 88-year-long master chronology was built (Figure 4). The first year of chronology was 1927 and the last was 2014. The average I of the master chronology is 1.003 , the standard deviation is 0.107 , the skewness -0.006 , and kurtosis 3.189. The mean sensitivity is 0.138 , and the serial correlation is -0.379 . The obtained version of the ars chronology was further used for determining the influence of climate parameters on tree-ring formation.

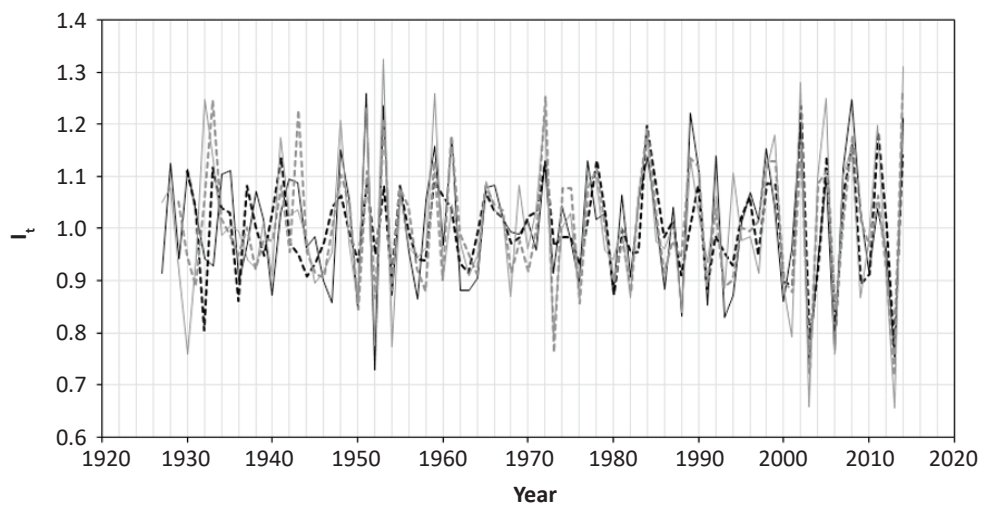

Figure 3. Site chronologies of silver fir - arstan version. 
Table 4. Correlation coefficients ( $r$ ) (upper triangular of the matrix) and Gleichläufigkeit (glk) (lower triangular of the matrix) between site chronologies.

\begin{tabular}{c|cccc}
\hline Site & Site 1 & Site 2 & Site 3 & Site4 \\
\hline Site 1 & $*$ & $r=0.693(p=0.00)$ & $r=0.713(p=0.00)$ & $r=0.742(p=0.00)$ \\
Site 2 & $g \mid k=0.699$ & $*$ & $r=0.647(p=0.00)$ & $r=0.688(p=0.00)$ \\
Site 3 & $g \mid k=0.698$ & $g \mid k=0.657$ & $*$ & $r=0.841(p=0.00)$ \\
Site 4 & glk=0.720 & $g \mid k=0.693$ & $g \mid k=0.738$ & $*$ \\
\hline
\end{tabular}

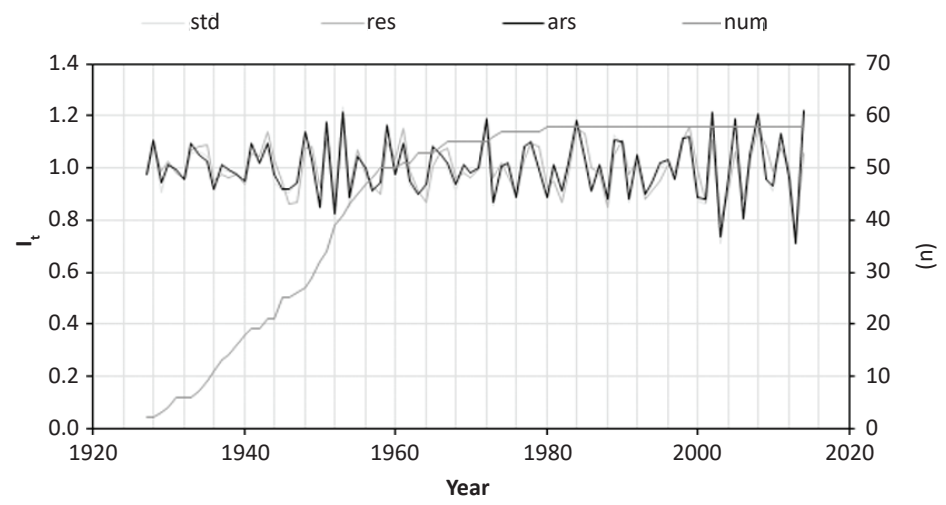

Figure 4. Master chronology of silver fir for Kozara Mountain - std (standardized), res (residual) and ars (arstan) version (num displays the number of tree-ring series in master chronology).

Pointer year was defined as the year when in a sample of 10 or more individual tree-ring series more than $90 \%$ of the series respond with the same increasing or decreasing trend in tree-ring width compared to the previous year (Schweingruber 1983, Schweingruber et al. 1990). The years 1951, 1953, 1955, 2007 and 2014 were determined as strong positive pointer years. On the other hand, the negative pointer years were 1936, 1954, 1973, 2000, 2003, 2006, 2009 and 2013 (Figure $5)$. It is indicative that the same number of negative pointer years was recorded since the beginning of the $21^{\text {st }}$ century (in only 15 years) as in the previous 64 years (in the 1936-1999 period).

Correlation analysis was performed to examine the relationship between annual tree-ring width and temperature and precipitation variability. The master chronology was correlated with the climate data on mean monthly temperature and precipitation. Given that the climate conditions in the period prior to the tree-ring formation affect its development in great measure (Fritts 1976), the correlation analysis covered thermal and pluvial conditions in the August-October of the previous growth year periods and in April-October of the current growth year periods.

Climatic description of the study area is given based on climatic data on mean monthly and annual temperature and precipitation from Prijedor meteorological station in the 1961-2014 period. The mean annual temperature in Prijedor is $11.0^{\circ} \mathrm{C}$. The warmest month is July with an average temperature of $21.3^{\circ} \mathrm{C}$, whereas the coldest month is January $\left(-0.3^{\circ} \mathrm{C}\right)$. The mean temperature of the growing season (April-October) is $17.5^{\circ} \mathrm{C}$. The average annual precipitation is $931 \mathrm{~mm}$. The maximum precipitation occurs in September (93 mm), whereas the minimum is recorded in February (55 $\mathrm{mm}$ ). During the 1961-2014 period, temperature displayed a significant upward trend in the summer season in the range of $0.58^{\circ} \mathrm{C}$ per decade $(p<0.01)$. In that period, the most prominent downward trend in precipitation was also determined in summer (-13.6 mm per decade, $p<0.07)$.

The relationship between the silver fir tree-ring width and the air temperature is mostly negative (Figure 6). The highest negative correlation coefficient was determined for September of the previous year $(r=-0.282)$ and then for summer months - July and August of the current growth year ( $r=-0.184$ and $r=-0.272$, respectively). High summer temperatures negatively affect the trees' radial growth. The obtained negative relation in the July-August period is in accordance with the results from previous studies suggesting that high summer temperatures limit tree growth, i.e. forest trees exposed to high temperatures and reduced humidity (water supply) produce narrower annual tree rings (Fritts 1976). A weak positive correlation was determined for April of the current growth year. Due to higher temperatures in April, tree-ring formation begins earlier, i.e. the growing season is prolonged, which positively affects the annual tree-ring width.

In contrast to temperature, the correlation between the silver fir tree-ring width and precipitation is stronger, more significant and predominantly positive, particularly at the beginning of the growing season, in April and May ( $r=0.175$ and $r=0.318$, respectively), and in the crucial July-September period ( $r$ in the range of $0.143-0.222$ ). Frequent lack of available moisture in this period of the year (July-September) 


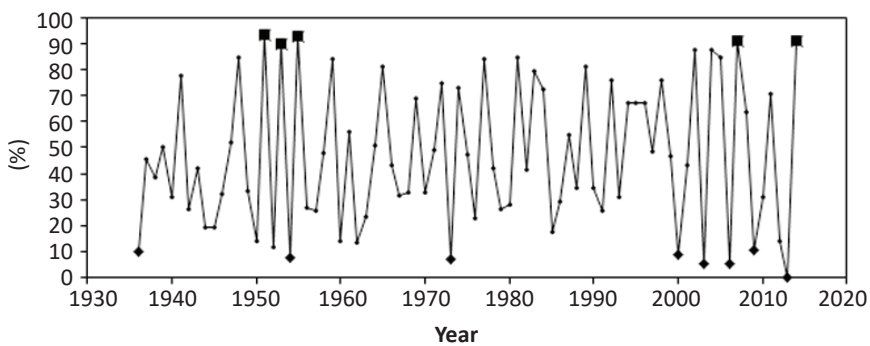

Figure 5. Positive (marked with a square) and negative (marked with a rhombus) pointer years in the master chronology of silver fir for Kozara Mountain.

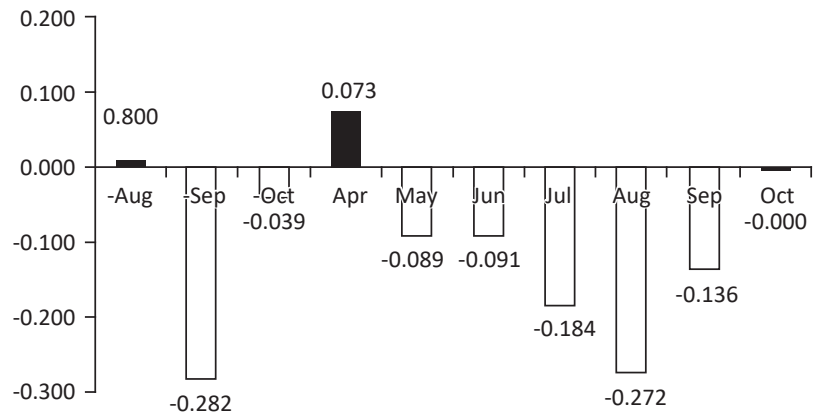

Figure 6. Correlation coefficients between silver fir master chronology tree-ring index (It) and mean monthly temperature from Prijedor meteorological station.

negatively affects the tree increment, i.e. slows down the formation of tree rings (Figure 7).

Based on the correlation analysis it could be concluded that precipitation has a greater impact on the tree-ring formation than temperature. When it comes to precipitation, correlation coefficient greater than 0.200 was determined for four months, whereas for temperature only for two months.

The forestry aridity index (FAI) represents the ratio of average temperatures in July and August, and rainfall from May to August. In this research, FAl was used in order to eliminate the consequences mutual inter-correlation between temperature and precipitation (higher temperatures also cause less precipitation and vice versa). The determined relationship between $I_{t}$ and FAI was significant and negative: with an increase in FAI (i.e. with increasing aridity), the tree ring width decreased. The determined correlation coefficient of -0.390 was statistically significant at the $99 \%$ level. This is in accordance with the previously stated fact that adequate water supply plays a crucial role in silver fir increment. During the 1961-2014 periods, six negative pointer years were

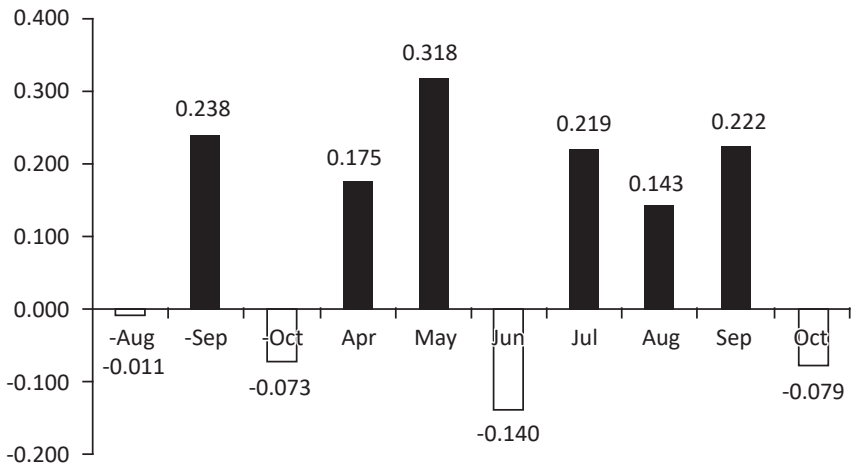

Figure 7. Correlation coefficients between silver fir master chronology tree-ring index (It) and monthly precipitation from Prijedor meteorological station. 
determined. For these negative pointer years, the average value of FAI was 8.1, whereas for the entire observed period it was 5.7. For the two positive pointer years, the average value of the FAl was 5.2.

The matching of years with minimum value of tree-ring width index $\left(\mathrm{I}_{t}\right)$ and minimum precipitation in July (2013) confirms that the standardization process was reasonable and well-performed. The lowest I, values were recorded in 2003 and 2013, in the years of secondary and tertiary minimum of FAl.

\section{DISCUSSION}

Pointer years detected in silver fir chronology for Kozara Mountain match relatively well with the chronology of silver fir from the Dinaric region in Slovenia, in which 11 negative and 9 positive pointer years during the 1900-1993 period have been determined (Levanič 1996). At several sites in Slovenia 1976, 1967, 1962, 1960, 1947 and 1942 were detected as negative pointer years, whereas 1989, 1961, 1959, 1951 and 1943 were detected as positive (Levanič 1996). According to Toromani et al. (2011), the most prominent negative pointer years in the silver fir chronology from the Koritnik Mountain (southern Kosovo) were 1985, 1997 and 2003. In the 64-year-long silver fir chronology from Kosovo, 1909, 1953, 1980 and 1995 were detected as strong negative pointer years, whereas 1947, 1955, 1971 and 1994 as positive (Toromani and Bojaxhi 2010). The authors in the study stated that the pointer years 1953 and 1955 appeared to be the most geographically extended pointer years for silver fir throughout Europe. The 9 negative (1874, 1880, 1891, 1931, 1943, 1963, 1971, 1987 and 2000) and 5 positive (1876, 1930, 1941, 1959 and 1969) pointer years were identified for Austrian pine (Pinus nigra) in Bosnia and Herzegovina (Poljanšek et al. 2012). The number of negative and positive years in the observed surveys is approximately the same as the determined number for the Kozara National Park area considering the chronology length, but the same characteristic years in different chronologies have not been observed.

Ducić et al. (2015) found that precipitation, i.e. drought in the summer months of July and August, is crucial for radial increment of the silver fir from Bokšanica Mountain (eastern Bosnia and Herzegovina). Statistically significant positive correlation coefficients between the residual ringwidth chronology and precipitation were determined for July (0.384) and August (0.367), whereas significant links of the opposite sign were found for January $(-0.313)$. Although the annual data displayed weak connections, for the growing season (April-October) a statistically significant correlation coefficient was determined (0.327). The significant relationship with air temperature was obtained only for July $(-0.288)$. The observed effect of precipitation on fir radial increment at Bokšanica Mountain is in accordance with the results obtained for the effect of precipitation at Kozara Mountain in summer (the effect of precipitation is also more prominent than the effect of air temperature).

Toromani and Bojaxhi (2010) determined that radial growth of silver fir in Kosovo depends strongly on spring temperature and precipitation (i.e. climate at the beginning of the growing season), which play a significant role particularly for early wood production. High spring temperatures and ample rainfall during the first part of the growing season had positive influence on silver fir growth (i.e. the formation of wide tree-rings) in southern Kosovo, whereas lower spring temperatures and scarce precipitation had an inverse effect (Toromani et al. 2011). Temperatures in April and May of the current growth year positively influenced silver fir growth at the low-elevation sites, whereas the July precipitation of the previous growth year had a negative effect (Toromani et al. 2011). More prominent effect of air temperature in comparison to the results obtained for Kozara Mountain, especially in spring, can be explained by the significantly higher altitudes of the investigated sites (1200 m and 1500 $\mathrm{m})$.

Bronisz et al. (2010) found that silver fir trees in Poland showed a significant negative relationship to thermal conditions in March and July-September periods. On the other hand, a positive correlation with water supply was observed in February and July. Additionally, silver fir trees at some sites showed a significant negative relation with precipitation in August of the year prior to the ring formation and in May of the current year.

Climate-growth relationship analysis determined that silver fir forests' growth at the south-western distribution limit in Europe is severely constrained by low spring-summer water availability, whereas in non-Mediterranean areas it is limited by cold conditions in the late winter-early spring periods (Gazol et al. 2015). The same study also found that most populations in the Mediterranean area have displayed a marked decline in growth since the 1980s (Gazol et al. 2015). Silver fir in marginal populations in central Italy showed a positive influence of late-spring and summer precipitations and a negative effect of summer temperatures, during the last century (Mazza et al. 2013). Moreover, the results suggested that the shifting influence of summer precipitation on tree-rings growth from July to August of the previous year is a possible response of silver fir to the significant reduction in spring precipitation and the general warming trend present throughout the $20^{\text {th }}$ century (Mazza et al. 2013).

Similar patterns of climate-growth relationship were found for Scots pine (Pinus sylvestris L.) and Austrian pine (Pinus nigra Arn.) in Bosnia and Herzegovina and in the surrounding area. The significant positive effects of aboveaverage temperatures in January-March were determined, whereas the above-average temperatures in May-August had a negative impact on Austrian pine increment (Poljanšek et al. 2012). Furthermore, a positive relationship between tree-ring width and above-average precipitation in MayAugust was found at several sites (Poljanšek et al. 2012). The fact that sufficient precipitation with a good distribution throughout the year has a strong positive influence on the radial growth of Austrian pine (Pinus nigra Arn.) was also observed in Serbia (Koprivica et al. 2009, Ćirković-Mitrović et al. 2013). According to Koprivica et al. (2009), in middleaged Austrian pine plantations, a statistically significant dependence of the diameter increment on the precipitation was determined, whereas the dependence on the air temperature and thinning is random. Ćirković-Mitrović 
et al. (2013) found a strong positive correlation between the trends in the diameter increment of Austrian pine and annual precipitation, but also with precipitation during the growing season (Ćirković-Mitrović et al. 2013).

Different patterns of climate dependence have been identified for silver fir trees in the northern part of the European continent. A dendroclimatological study of silver fir growing in the Kaszubskie Lakeland in northern Poland showed that winter temperature and precipitation have the most important effect on fir radial growth (Bijak 2010). During the observed 1914-2006 period, tree-ring width was strongly dictated by winter, early spring and summer temperatures, whereas a significant relation with moisture availability was determined only for January. Given the results, it seems that in colder Poland silver fir prefers warm and dry winters and, to some extent warmth in early spring and in the middle part of the growing season.

Climate change (lack of precipitation, increase in temperature, increase in intensity or frequency of extreme weather events, etc.) is expected to have a strong impact on silver fir radial growth (Dobrowolska et al. 2017). Stojanović et al. (2012) used the Forestry Aridity Index to evaluate the impact of climate change on beech forests in Serbia. The obtained results showed that the 1981-2010 period was drier compared to the 1961-1990 period. Matovic (2013) investigated the impact of climate change by the end of the $21^{\text {st }}$ century on the future growth and distribution of the main tree species in Montenegro, including the silver fir. Based on the FAl, it was determined that, according to the EBU-POM regional climate model (Djurdjević and Rajković 2010 ), in the $2071-2100$ period, about $19.1 \%$ of the primary areas where the presence of silver fir was identified would be outside the existing ecological niches (that is, the area in which the silver firs can successfully survive based on their internal and physiological constraints). Compared to other species such as spruce or beech, the percentage of decrease is significantly higher (Matović 2013).

The results of radial growth-climate analysis obtained in this study are similar to the results of other studies in Bosnia and Herzegovina and in the surrounding area, which addressed the issues of the silver fir's (and other conifer species') growth dependence on climate. It can be assumed that the dependence of radial growth on climatic variables is less pronounced (relatively small values of correlation coefficients), due to the fact that they are localities with good habitat conditions for silver fir (soil characteristics, altitude, etc.). The structure of a forest stand also has effect on the dependence of radial growth on climatic variables, i.e. the values of correlation coefficients. Trees in overstocked stands are crowded and less vigorous.

\section{CONCLUSIONS}

The results of the current study contribute to a better understanding of silver fir radial tree growth at Kozara Mountain. Based on core samples extracted from 58 trees at four sites in the broader Mrakovica area, the first silver fir master chronology for this area was built. In the 88-year-long master chronology developed, five positive and eight negative pointer years were identified. Climate is an important site factor, which has a direct impact on silver fir radial growth. Analysis of tree-rings growth dependence on climate variables revealed that precipitation has a stronger impact on tree-ring formation than temperature. The negative impact of high summer temperatures was also determined. A significant positive trend in the $\mathrm{FAl}$, which indicates an increase in aridity, negatively affects the tree-ring growth. Considering the detected tree-ring formation dependence on precipitation and temperature, especially during the summer season, it is particularly important to highlight that climate change in the study area is most prominent during this part of the year. During the 1961-2014 period, temperature displayed a significant upward trend in the summer season in the range of $0.58^{\circ} \mathrm{C}$ per decade. In that period, the most prominent downward trend in precipitation was also determined in summer (-13.6 $\mathrm{mm}$ per decade).

Studies on the impact of high temperatures and low precipitation (i.e. drought) on the radial tree growth of silver fir are certainly significant. Knowledge on these impacts is of great importance in the making and implementation of management plans (including silvicultural treatment) for the conservation of sensitive ecosystems and tree species in protected areas.

\section{Author Contributions}

JS, VD, ZM, GT conceived and designed the research, JS and VD carried out the field measurements, DP and JS performed laboratory measurements, JS, TP processed the data and performed the statistical analysis. All authors contributed to data collection and manuscript writing.

\section{Funding}

This research received no external funding.

\section{Acknowledgments}

The authors would like to thank MSc Dragan Romčević, Director of Kozara National Park, for their support during the fieldwork.

\section{Conflicts of Interest}

The authors declare no conflict of interest.

\section{REFERENCES}

Amoroso MM, Baker PJ, Daniels, LD, Camarero JJ, 2017. Introduction. In: Amoroso, MM, Daniels LD, Baker, PJ, Camarero JJ (eds) Dendroecology: Tree-Ring Analyses Applied to Ecological Studies. Ecological Studies (Analysis and Synthesis), vol 231. Springer, Cham, The Netherlands, pp. 1-9. https://doi. org/10.1007/978-3-319-61669-8 1.
Badea O, Tanase M, Georgeta J, Anisoara L, Peiov A, Uhlirova H, Pajtik J, Wawrzoniak J, Shparyk Y, 2004. Forest health status in the Carpahian Mountains over the period 1997-2001. Environ Pollut 130(1): 93-98. https://doi.org/10.1016/j.envpol.2003.10.024.

Baillie MGL, Pilcher JR, 1973. A simple cross-dating program for tree-ring research. Tree-Ring Bulletin 33: 7-14. 
Beus V, 1984. Vertical diversification of forests in light of the real and primary vegetation in Yugoslavia. Radovi Odjeljenja prirodnih $i$ matematičkih nauka ANUBiH 23: 23-32. (in Croatian).

Bijak S, 2010. Tree-ring chronology of silver fir and its dependence on climate of the Kaszubskie lakeland (Northern Poland). Geochronometria 35(1): 91-94. https://doi.org/10.2478/ v10003-010-0001-9.

Bronisz A, Bronisz K, Bijak Sz, Tomusiak R, Wojtan R, Zasada M, 2010. Dendroclimatological investigation on radial growth of silver fir from inside and outside distribution range in Poland. In: Levanic T, Gricar J, Hafner P, Krajnc R, Jagodic S, Gärtner H, Heinrich I, Helle G (eds) TRACE - Tree Rings in Archaeology, Climatology and Ecology, Vol. 8: Proceedings of the DENDROSYMPOSIUM 2009, Otočec, Slovenia, 16-19 April 2009. GFZ German Research Centre for Geosciences, Potsdam, Germany, pp. 6-13.

Carrer M, Nola P, Motta R, Urbinati C, 2010. Contrasting tree-ring growth to climate responses of Abies alba toward the southern limit of its distribution area. Oikos 119(9): 1515-1525. https:// doi.org/10.1111/j.1600-0706.2010.18293.x.

Cook ER, 1985. A time-series analysis approach to tree-ring standardization. PhD Thesis, University of Arizona, Tucson, USA, $171 \mathrm{p}$.

Cook ER, Peters K, 1981. The smoothing spline: A new approach to standardizing forest interior tree-ring width series for dendroclimatic studies. Tree-Ring Bulletin 41: 45-53.

Cook ER, Holmes RL, 1997. ARSTAN: chronology development. In: Grissino Mayer HD, Holmes RL, Fritts HC (eds) The International Tree-Ring Data Bank Program Library Version 2.1 User's Manual. Laboratory of Tree-Ring Research, The University of Arizona, Tucson, AZ, USA, pp. 75-92.

Čabaravdić A, Dundjer A, Avdagić A, Delić S, Osmanović $M$, Mraković A, 2016. Bosnia and Herzegovina. In: Vidal C, Alberdi I, Hernández Mateo L, Redmond J (eds) National Forest Inventories: Assessment of Wood Availability and Use. Springer, Cham, Switzerland, pp. 181-196. https://doi.org/10.1007/978-3319-44015-6 9.

Ćirković-Mitrović T, Popović V, Brašanac-Bosanac Lj, Rakonjac $L j$, Lučić A, 2013. The impact of climate elements on the diameter increment of Austrian Pine (Pinus nigra Arn.) in Serbia. Arch Biol Sci 65(1): 161-170. https://doi.org/10.2298/ABS1301161C.

Djurdjević V, Rajković B, 2010. Development of the EBU-POM coupled regional climate model and results from climate change experiments. In: Mihajlović TD, Lalić B (eds) Advances in Environmental Modeling and Measurements. Nova Science Publisher Inc., New York, USA, pp 29-32.

Dobrowolska D, Bončina A, Klumpp R, 2017. Ecology and silviculture of silver fir (Abies alba Mill.): A review. J For Res 22(6): 326-335. https://doi.org/10.1080/13416979.2017.1386021.

Drinić P, Matić V, Pavlić J, Prolić N, Stojanović O, Vukmirović V, Koprivica M, 1990. Tables of taxation elements of high and coppice forests in Bosnia and Herzegovina. University of Sarajevo, Faculty of Forestry, Sarajevo, Bosnia and Herzegovina, 327 p. (in Serbian).

Ducić V, Ivanović R, Mihajlović J, Gnjato R, Trbić G, Ćurčić N, 2015. Dendroindication of drought in Rogatica region (Eastern Bosnia). Arch Biol Sci 67(1): 201-211. https://doi.org/10.2298/ ABS141114025D.

Eckstein D, Bauch J, 1969. Contribution to the rationalization of a dendrochronological procedure and to the analysis of its reliability. Forstwiss Centralb/ 88(4): 230-250. (in German).

Elling W, Bretschneider M, Schwarzfischer C, 1999. Depression of fir growth due to sulfur emissions. Allg Forst-Zeitschrift 54: 896898. (in German).

Filipiak M, 2005. Changes of silver fir (Abies alba Mill.) crown state and stand quality class in Sudety Mountains. Dendrobiology 54: 11-17.

Filipiak M, 2006. Life of Abies alba (Pinaceae) under the conditions of intense anthropopressure in the Sudety Mountains. Fragm Flor Geobot Polonica 13: 113-138. (in Polish).
Filipiak M, Napierała-Filipiak A, 2009. Effect of canopy density on the defoliation of the European silver fir (Abies alba Mill.) due to heavy industrial pollution. Dendrobiology 62: 17-22.

Fritts HC, 1976. Tree rings and climate. Academic Press, New York and San Francisco, USA, $567 \mathrm{p}$.

Führer E, Horváth L, Jagodics A, Machon A, Szabados I, 2011. Application of new aridity index in Hungarian forestry practice. Idojárás 115(3): 205-216.

Gazol A, Camarero JJ, Gutiérrez E, Popa I, Andreu-Hayles L, Motta R, Nola P, Ribas M, Sangüesa-Barreda G, Urbinati C, Carrer M, 2015. Distinct effects of climate warming on populations of silver fir (Abies alba) across Europe. J Biogeogr 42(6): 1150-1162. https:// doi.org/10.1111/jbi.12512.

Grissino-Mayer HD, 2001. Evaluating crossdating accuracy: A manual and tutorial for the computer program COFECHA. TreeRing Res 57(2): 205-221.

Holmes RL, 1983. Computer-assisted quality control in tree-ring dating and measurement. Tree-Ring Bulletin 43: 69-78.

Huber B, 1943. About the accuracy of tree-ring chronological dating. Holz Roh Werkst 6: 263-268. (in German).

Jović G, Dukić V, Stajic B, Kazimirovic M, Petrović D, 2018. A dendroclimatological analysis of fir (Abies alba Mill.) growth in the Borja Mountain area of Bosnia and Herzegovina. Bulletin of the Faculty of Forestry (University of Belgrade) 118: 27-46. DOI: https://doi.org/10.2298/GSF1818027J.

Koprivica M, Matović B, Stajić S, Čokeša V, 2009. Diameter increment trend of the Austrian pine plantations in Raška, Sustainable forestry-Collection, pp 59-60.

Koprowski M, 2013. Reaction of silver fir (Abies alba) growing outside its natural range to extreme weather events and a longterm increase in March temperature. Tree-Ring Res 69(2): 49-61. https://doi.org/10.3959/1536-1098-69.2.49

Levanič T, 1996. Dendrochronological and dendroecological study of dominant and co-dominant declining silver fir (Abies alba Mill.) in Dinaric phytogeographic region. PhD Thesis, University of Ljubljana, Biotechnical Faculty, Department of Forestry, Ljubljana, Slovenia. (in Slovenian).

Matović B, 2013. Analyzes and projections of climate change impacts using a regional climate model on the future distribution and growth of major tree species in Montenegro. Final Report, Ref. No. UNDP MNE 13-026, UNDP, Podgorica, Montenegro. (in Serbian).

Mazza G, Gallucci V, Manetti Mc, Urbinati C, 2013. Tree-ring growth trends of Abies alba Mill: Possible adaptations to climate change in marginal populations of central Italy. Open For Sci J 6: 46-49. https://doi.org/10.2174/1874398601306010046

Poljanšek S, Ballian D, Nagel Ta, Levanič T, 2012. A 435-year-long european black pine (Pinus nigra) chronology for the CentralWestern Balkan Region. Tree-Ring Res 68(1): 31-44. https://doi. org/10.3959/2011-7.1.

Poljanšek S, Ceglar A, Levanič T, 2012. Long term January-March and May-August temperature reconstructions from tree-ring records from Bosnia and Herzegovina. Clim Past 8(5): 4401-4442. https://doi.org/10.5194/cpd-8-4401-2012.

Rolland C, 1983. Tree-ring and climate relationships for Abies alba in the internal Alps. Tree-Ring Bulletin 53: 1-11.

Schweingruber FH, 1983. The tree ring. Verlag Paul Haupt, Bern and Stuttgart, Germany, 234 p. (in German).

Schweingruber FH, Eckstein D, Serre-Bachet F, Bräker OU, 1990. Identification, presentation and interpretation of event years and pointer years in dendrochronology. Dendrochronologia 8: 9-38.

Smith KT, Čufar K, Levanič T, 1999. Temporal stability and dendroclimatology in silver fir and red spruce. Phyton 39: 117122.

Smith DJ, Lewis D, 2007. Dendrochronology. In: Elias SA (ed) Encyclopedia of Quaternary Science, $1^{\text {nd }}$ edn. Elsevier, Amsterdam, The Netherlands, pp. 459-465. 
Stefanović V, 1977. Phytocenology with a review of forest phytocenoses of Yugoslavia. Zavod za udžbenike, Sarajevo, Bosnia and Herzegovina, 283 p. (in Serbian).

Stefanović V, Beus V, Burlica Č, Dizdarević H, Vukorep I, 1983. Ecological-vegetation regionalization of Bosnia and Herzegovina. Faculty of Forestry, Sarajevo, Bosnia and Herzegovina, 51 p. (in Serbian with English summary).

Stojanović D, Matović B, Orlović S, Kržič A, Đurđević V, Galić Z, Vuković $A$, Vujadinović $M, 2012$. The use of forest aridity index for the evaluation of climate change impact on beech forests in Serbia. Topola 189-190: 117-123. (in Serbian with English summary).
Toromani E, Bojaxhi F, 2010. Growth response of silver fir (Abies alba Mill) and bosnian pine (Pinus heldreichii Christ) from Kosovo. South-east Eur for 1(1): 20-27. https://doi.org/10.15177/ seefor.10-03

Toromani E, Sanxhaku M, Pasho E, 2011. Growth responses to climate and drought in silver fir (Abies alba) along an altitudinal gradient in southern Kosovo. Can J For Res 41(9): 1795-1807. https://doi.org/10.1139/x11-096.

Uščuplić M, 1992. Impact of management system on mistletoe occurrence (Viscum album L.). Bulletin of the Faculty of Forestry (University of Belgrade) 74: 7-18. (in Bosnian).

Uščuplić $M$, Dautbašić $M$, Treštić T, Selman $E$, Mujezinović $O$, Nišić T, Jokanović B, 2007. Diseases and pests of common fir (Abies alba Mill.) in Bosnia and Herzegovina. Plant Protection Society of Bosnia and Herzegovina, Sarajevo, Bosnia and Herzegovina, 114 p. (in Bosnian). 